\title{
Figuras de la pobreza en la escritura quevediana
}

\author{
Marcella Trambaioli \\ Università del Piemonte Orientale, \\ Dipartimento di Studi Umanistici \\ P.za S. Eusebio, 5 \\ 13100 Vercelli \\ Italia \\ marcella.trambaioli@uniupo.it
}

[La Perinola, (Issn: 1138-6363), 22, 2018, pp. 325-345]

DOI: $10.15581 / 017.22 .325-345$

En las letras auriseculares el tema de la pobreza con las figuras y aspectos que al mismo se relacionan se suele encontrar o bien en tratados morales y en textos religiosos vinculados al rechazo de los bienes materiales por parte de órdenes monásticas como los franciscanos y los dominicos, así como de los reformistas (erasmistas, protestantes), o bien en la literatura picaresca, considerada en un amplio sentido y de manera transgenérica (prosa, teatro breve, poesía satírico-burlesca), donde el pobre es un «hecho social» ${ }^{1}$. Cabe advertir que el tratamiento del tipo resulta decididamente sui generis en las obras lopescas, donde la penuria material de los personajes varoniles resulta ser un leitmotiv literario con claras repercusiones autobiográficas, a partir de los tonos patéticos con los cuales el poeta exalta la indigencia de tal o cual protagonista -en cierta medida máscara autorial- para hacer resaltar sus cualidades morales y pedir, de forma oblicua, favores cortesanos; es lo que ocurre, por ejemplo, en la comedia Las pobrezas de Reinaldos ${ }^{2}$.

Sea como fuere, la literatura del pobre se inserta, ante todo, en un discurso ideológico vinculado al paso histórico de la economía feudal a

1. Rodríguez, 1994, p. 19.

2. Ver Trambaioli, 2016 , p. 125: «en el teatro lopesco el tema de la pobreza resulta muy provechoso y funcional en un doble sentido: temático y metateatral. En el cierre de la obra, sea cual fuere el subgénero dramático, los galanes pobres reciben el reconocimiento y las dádivas proporcionales a sus méritos y virtudes, hallando en cada caso a un poderoso dispuesto a concedérselos. Mediante la elaboración del tema de La Dorotea, y el recurso a máscaras teatrales el Fénix consigue fácilmente relacionar dicho aspecto del desenlace a sus personales motivaciones autopromocionales, pero cabe reconocer que a lo largo y a lo ancho de su larga carrera literaria las mismas no surten ningún resultado, dado que ni la Corte, ni los aristócratas que el poeta frecuenta en Madrid y en las capitales del poder periférico las toman en cuenta». 
la economía capitalista que conlleva cambios socio-económicos y determina la crisis de identidad de la nobleza ${ }^{3}$. Rodríguez, a propósito de la relación entre literatura picaresca y las transformaciones sociales de la modernidad temprana, asegura:

no hay un solo texto que muestre mejor la existencia del desorden como clave de las relaciones sociales de la Transición que el comienzo de $E l$ Buscón quevedesco. Ya que, en efecto, es el desorden el verdadero objeto ideológico que la obra trata de producir incluida toda una larga serie de connotaciones inscritas en tal campo ${ }^{4}$.

Sea cual fuere la interpretación que pretendamos asignar al Buscón, es un hecho que la escritura de Quevedo nos depara un abigarrado e intrigante desfile de figuras y figurillas ${ }^{5}$, así como una casuística situacional sobre el tema en cuestión que nos permite abarcar el estudio de la literatura del pobre tanto en su vertiente seria como en su dimensión burlesca. Con respecto a la segunda está claro que, según apunta Chevalier, el escritor no sigue el precepto de la urbanitas recomendada por Luis Zapata y otros tratadistas de los siglos XVI y xvir según el cual es impropio y cruel hablar contra el pobre y el afligido ${ }^{6}$.

De entrada, notemos cómo la visión del pobre según una óptica meditativa y moralizadora, impregnada de estoicismo ${ }^{7}$, se cristaliza a la perfección en una redondilla que aparece en una versión del Heráclito cristiano:

Si soy pobre en mi vivir

y de mil males cautivo, más pobre nací que vivo, y más pobre he de morirs.

Mediante la reiteración del adjetivo que denota la condición de necesidad y la simbólica antítesis entre vida y muerte el autor remite a la pobreza espiritual de quien permanece apegado a los falsos valores terrenales.

3. Ver al respecto, Geisler, 2013.

4. Rodríguez, 1994, p. 45. Por su parte Schwartz Lerner, 1989, p. 623, así reflexiona: «Quevedo no se me presenta como una persona que pudiera salirse de sus códigos ideológicos con facilidad. Sin embargo, la crisis económica sí era parte de su realidad, como lo señala El chitón de las tarabillas y más de un capítulo de La hora de todos, por sólo mencionar dos obras». Sobre las concepciones quevedianas de la pobreza, ver también Peraita, 2004.

5. Arellano, 1984, p. 101, las clasifica en el número de las «figuras sociales» marginalizadas por la ideología oficial.

6. Chevalier, 1992, pp. 58-59.

7. Alonso, 1966, p. 499, destaca «la cadena de moralistas estoicos tardíos (Séneca, Epicteto, Marco Aurelio, etc.), de la cual Quevedo es una prolongación».

8. Quevedo, «Recuerdo y consuelo en lo mísero de esta vida», en Poesía varia, p. 516; el editor, p. 517, en el «comentario» al salmo «Bien te veo correr, Tiempo ligero» aclara que se trata de "una serie titulada "Lágrimas de un penitente", impresa en Las tres musas últimas castellanas (1670)». 
Las sagradas escrituras ofrecen a la pluma de Quevedo la figura ejemplar de quien, teniéndolo todo, todo lo pierde y se resigna a la voluntad divina. Destaquemos con Nider que en La constancia y paciencia del santo Job, «el narrador se apresura a detallar las hiperbólicas virtudes del protagonista antes de enumerar sus extraordinarios bienes, para evitar que los lectores piensen en los pecados que siempre conlleva la prosperidad» ${ }^{9}$. En el capítulo Pobreza. Segunda fantasma de la vida, de Virtud militante contra las cuatro pestes del mundo, el autor cita las enseñanzas que Cristo nos ha dejado con respecto a la corrupción moral que suele acompañar la riqueza: «Más fácil es que pase un camello por el ojo de una aguja, que entrar el rico en el Reino de los Cielos [...] vete, $\mathrm{y}$ vende todo lo que tienes, y dalo a los pobres, y tendrás tesoro en el Cielo, y ven, y sígueme» ${ }^{10}$.

Así, pues, la riqueza material, si no se acompaña con la dimensión ética preconizada por Cristo y puesta en práctica por Job, acaba transformándose en su contrario ${ }^{11}$. Quevedo, conforme a la sátira de los tacaños que se remonta al Antiguo Testamento, deja constancia de ello en varias composiciones, ante todo en las dos redondillas tituladas «A un avariento»:

En aqueste enterramiento

humilde, pobre y mezquino,

yace envuelto en oro fino

un hombre rico avariento.

Murió con cien mil dolores,

sin poderlo remediar,

tan solo por no gastar

ni aun hasta malos humores ${ }^{12}$.

Según se puede apreciar en estos versos dominados por la tópica figura del «rico avariento», la mezquindad del hombre no solo se reverbera en su humilde sepultura sino también en los síntomas de la enfermedad que lo ha llevado a la tumba. Y puesto que el rico suele ser avaro y codicioso, revelando su miseria moral, don Francisco compone el soneto «Enseña cómo no es rico el que tiene mucho caudal». La voz poética, dirigiéndose a un tal Casimiro, dictamina con ecos de Epicuro citado por Séneca en su Epístola 21 a Lucinio ${ }^{13}$ : «Quitar codicia, no

9. Nider, 2017, p. 129; la estudiosa observa asimismo que el protagonista reconoce que: «Dios da y quita. Este proceso culmina en el clímax del regressus ad uterum al declarar Job que así como nació desnudo del útero de su madre, va a regresar desnudo al mismo» (p. 131).

10. Quevedo, Virtud militante contra las cuatro pestes del mundo, p. 264 [he modernizado la grafía].

11. Schwartz Lerner, 1989 , p. 624, recorta varios textos donde Quevedo defiende que «la prosperidad pierde al hombre», conforme al «pensamiento escolástico que desde la Summa Theologiae incorporan los comentarios de Aristóteles en su Política, I, 6 y 7, para considerar la dimensión ética de operaciones económicas».

12. Quevedo, "A un avariento», en Poesía varia, p. 49.

13. Lo apunta Crosby, en Quevedo, Poesía varia, p. 148. 
añadir dinero, / hace ricos a los hombres», y concluye remachando: «Descifra las mentiras del tesoro, / pues falta (y es del Cielo este lenguaje) / al pobre mucho, y al avaro todo» ${ }^{14}$. De forma paradójica, pues, el acaudalado acaba siendo moralmente más necesitado que el que carece de recursos materiales.

Desde luego es en el capítulo iII de El Buscón donde la figura del tacaño adquiere un tratamiento hiperbólico en clave satírica con el personaje del licenciado Cabra, en cuya casa don Alonso pone a su hijo don Diego de pupilaje en compañía de Pablo. El propio pícaro, recordando el hambre padecida en su casa, lo define con dos neologismos característicos del ingenioso estilo quevediano: «archipobre y protomiseria» ${ }^{15}$. Verdad es que el retrato de Cabra excede la mera caricatura, siendo la deformidad física y su insuperable avaricia reflejos de su aridez interior $^{16}$. No obstante, el que dicha figura grotesca resulte funcional a un planteamiento ético o eminentemente estético se halla, de nuevo, en relación con la lectura que cada crítico quiera otorgar al Buscón ${ }^{17}$.

Los pobres que se mencionan en los Sueños suelen oponerse simbólicamente a los poderosos con vistas a crear un contrapunto conforme al tópico del Gran Teatro del Mundo, elaborado por los antiguos y actuali-

14. Quevedo, «Enseña cómo no es rico el que tiene mucho caudal», en Quevedo, Poesía varia, p. 147, vv. 1-2, y 12-14.

15. Quevedo, El Buscón, p. 118; comenta a este propósito Chevalier, 1992, p. 115: «Este tipo de creaciones idiomáticas, al cual había de dar su ingenio un lustre fuera de lo común, se había manifestado en las letras españolas antes de que saliera Quevedo a la palestra literaria: aparece en los versos de Sebastián de Horozco, en las Cartas de Eugenio de Salazar, en la prosa de Guzmán de Alfaraches; el propio crítico francés destaca asimismo que el tema de la pobreza resulta especialmente adecuado para los equívocos semánticos entre las figuras del motejar (pp. 47-48); por su parte, Vilanova, 1996, p. 366, identificando en el Euclión de Plauto uno de los modelos paradigmáticos a partir de los cuales Quevedo conforma su esperpéntico personaje, se fija en «los términos de que se valen los dos cocineros Antrax y Congrio para describir la extremada avaricia de Euclión, al que califican respectivamente de "hombre miserablemente mísero", mortalem parce parcum (II, IV, 314), y de "viejo misérrimo", senem parcissimum (II, IV, 335), superlativo este último que, junto con la expresión adverbial anteriormente citada, parece haber inspirado la lapidaria definición quevedesca del Dómine Cabra: "Al fin, él era archipobre y protomiseria"».

16. Apuntemos al respecto con Iffland, 1978, vol. 1, pp. 106-107: «the portrait of Licenciado Cabra tell us nearly all that need be said about his character before we see him in action, his physical deformity being simply an outward sign of his inward moral decay $[\ldots]$ the exaggeration and distortion is so great that it exceeds mere caricature; indeed, it constitutes an example of the substitution of norms for "anti-norms", a disintegration of the human form and a reconstruction of it along new line».

17. Al contrario del citado Rodríguez, 1994, p. 45, quien defiende una actitud ideológica, entre otros, Ynduráin, en el ensayo introductorio de su edición, p. 65, subraya la postura contraria: "para Quevedo el mundo no es caótico; muy al contrario, la alteración en las formas significa simplemente que nuestro autor reorganiza la realidad para adecuarla a sus fines, a su conveniencia [...] Los fines del autor son bien claros: producir un efecto de sorpresa admirativa. Quevedo manipula la realidad, las convenciones, los modelos, para hacer literatura libre»; lo mismo afirma Nolting-Hauff, 1968, p. 161; ver también en términos generales Prieto, 1970. 
zado por los escritores barrocos ${ }^{18}$. Concretamente, en El Sueño del Juicio Final la muerte igualadora borra las diferencias entre los estamentos sociales, tal como el yo paramimético, desde su atalaya, subraya con la cínica ironía de quien castigat ridendo mores ${ }^{19}$ : Era de ver cómo se entraban algunos pobres entre media docena de reyes que tropezaban con las coronas, viendo entrar las de los sacerdotes tan sin detenerse ${ }^{20}$.

En la letrilla «La pobreza. El dinero» la voz poética aprovecha la misma contraposición, lanzando al lector interrogaciones de naturaleza moral:

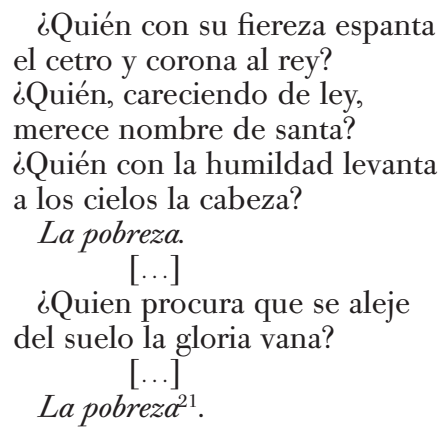

Adviértase que en dicha composición satírico-burlesca el escritor escoge la categoría abstracta para poder crear un juego estrófico y rítmico,

18. Fruto Cortés, en Calderón, El gran teatro del mundo, pp. 25-26: «El tema de la vida como teatro es antiquísimo. Aparece sobre todo en los pitagóricos, estoicos y neoplatóni$\cos [\ldots]$ En Séneca se encuentra el tema en las Epistolas a Lucilio. Pasó a los neoplatónicos, encontrándose varios pasajes de Plotino en que se glosa. [...] La vuelta a los autores antiguos renovó el tema en el Renacimiento. Valbuena cree que el antecedente más directo, o al menos, si fuese posterior, muy directamente emparentado con el desarrollo calderoniano, se encuentra en la traducción en verso de Quevedo (Epicteto y Focílides en español con consonantes, Madrid, 1635)».

19. Schwartz Lerner, 1989, p. 620, apunta: «Ettinghausen, como Blüher y Rothe, expresaban, sin duda, lo que todo lector de Quevedo advierte, es decir, que algunos pasajes satíricos se acercan a ciertas secciones de sus obras doctrinales. Quevedo mismo parece darnos la clave de esta lectura cuando titula a un largo poema de 1625 Sermón estoico de censura moral, y lo inicia con dos versos que imitan el famoso verso de la sátira 2 de Persio».

20. Quevedo, El Sueño del Juicio Final, en Sueños y discursos, p. 77; a este propósito reconoce Nolting-Hauff, 1968, p. 117: «la figura del labrador pobre es casi idéntica al pobre de Quevedo, una de las pocas figuras en los Sueños vistas de un modo totalmente positivo (y, por tanto, poco perfiladas). También esto - el que solamente los representantes de los estamentos sociales más bajos respondan al ideal cristiano de la virtud- pertenece a la convención de las danzas de la muerte, que aún sigue influyendo en El gran teatro del mundo de Calderón»).

21. Quevedo, “La pobreza. El dinero», en Poesía original completa, pp. 656-657, vv. 16-22, 30-31; a propósito de esta composición comenta Alonso Veloso, 2007, p. 94: «Sin duda, el ánimo de provocar la reflexión del oyente, y despertar su conciencia, así como el uso de términos del tipo "pobreza" y "dinero" aproximan esta letrilla satírica a la órbita de las composiciones de carácter moral [...] en este sentido resulta significativo el "abuso" de la figura retórica de la interrogation. 
a través de las rimas, que opone la pobreza al dinero, es decir el móvil de toda posible corrupción humana.

A manera de corolario de lo que acabamos de poner de relieve, en el infierno que don Francisco pinta con imágenes alegóricas y tonos sombríos análogos a los de Dante y Bosco no puede haber pobres porque, tal como asienta el diablo del Sueño del alguacil endemoniado, los que no tienen nada tampoco tienen razones para terminar allí:

Si lo que condena a los hombres es lo que tienen del mundo, y ésos no tienen nada, ¿cómo se condenan? Por acá los libros nos tienen en blanco. $\mathrm{Y}$ no os espantéis, porque aun diablos les faltan a los pobres. Y a veces, más diablos sois unos para otros que nosotros mismos. ¿Hay diablo como un adulador, como un envidioso, como un amigo falso y como una mala compañía? Pues todos éstos les faltan al pobre, que no le adulan, ni le envidian, ni tiene amigo malo ni bueno, ni le acompaña nadie. Estos son los que verdaderamente viven bien y mueren mejor ${ }^{22}$.

En íntima relación con este hecho, en el Sueño del Infierno un demonio revela al yo paramimético que los pecadores que sufren las penas infernales se quejan por no haberse portado según las enseñanzas del Evangelio, lamentando, entre otras cosas: «iOh, quién hubiera favorecido al pobre! $)^{23}$.

Sobre el tema candente de la justicia, en la escritura de don Francisco «solo el pobre está sujeto a la ley mientras que el rico goza de injusta impunidad», según apunta Arellano comentando los siguientes versos de la letrilla satírica «Toda esta vida es hurtar»:

Nadie verás castigar porque hurta plata o cobre: que al que azotan es por pobre de suerte, favor y trazas ${ }^{24}$.

No obstante, cuando el pobre se convierte en blanco de la pluma satírica e ingeniosa del escritor, salen a relucir las tachas de su tipo picaresco. A fin de cuentas, la burla quevedesca es aristocrática, «basada en la idea de que sólo los humildes, los marginados pueden ser objetos de risa», según advierte Roncero ${ }^{25}$. Así, pues, en su prosa festiva se hallan censuras del necesitado por su naturaleza engañosa o hasta necia. Por ejemplo, en la Pregmática de aranceles generales leemos:

22. Quevedo, El Sueño del alguacil endemoniado, en Sueños y discursos, p. 102; comenta al respecto el editor en su “Introducción» de la obra: “Aquí reside, acaso, la suprema ironía del discurso: el demonio dice verdades como puños» (p. 17).

23. Quevedo, El Sueño del Infierno, en Sueños y discursos, p. 127.

24. Arellano, 1984, p. 84; Quevedo, “Toda esta vida es hurtar», en Poesía original completa, p. 653, vv. 7-10; Gactó Fernández, 1996, p. 140, apunta que «continuas alusiones a la arbitrariedad de los jueces salpican Los sueños y la poesía satírica».

25. Roncero, 2006, p. 325. 
Los que cuando el reloj toca la hora preguntan cuántas da, siéndoles más fácil y decente contarlas, lo cual procede las más veces de humor colérico abundante, mandamos a los tales que tengan mucha cuenta con su salud $y$, siendo pobres que el hermano mayor los mande recoger al hospital, donde sean preparados con algunas guindas o naranjas agrias, porque corre[n] riesgo de ser muy presto modorros ${ }^{26}$.

Sobre la estupidez de ciertos pobres se fija el autor en un texto ad hoc: “Origen y difinición de la necedad, con anotaciones a algunas necedades de las que se usan»:

Declárase por necio de más quilates que el oro más subido de Tíbar, y por ignorante, con una punta de homicida de sí mismo, al que teniendo el estómago a teja vana y el vientre vació, convidándole a comer una y dos veces, dice que ya es después ${ }^{27}$.

Las difíciles relaciones entre los dos sexos, en el álveo de la destacada vena misógina de Quevedo ${ }^{28}$, ofrecen un sin fin de pretextos para recurrir en clave festiva y grotesca al motivo de la pobreza. Como es de esperar, la mujer se retrata como vieja y / o dueña ${ }^{29}$ que desprecia al miserable sin recursos crematísticos, parodia rebajadora del tópico del amor cortés según el cual la dama se niega al enamorado ${ }^{30}$. En el romance «Advertencia de una Dueña a un Galán pobre», la esperpéntica protagonista, descrita como «picaza de estrado», "pantasma de las doncellas», (gomia de los billetes», entre otros apodos estrafalarios ${ }^{31}$, liquida al pretendiente pobre tratándolo con sorna y desprecio:

26. Quevedo, Pregmática de aranceles generales, en Prosa festiva, p. 168.

27. Quevedo, Origen y difinición de la necedad, con anotaciones a algunas necedades de las que se usans en Prosa festiva, p. 202.

28. Ver a dicho respecto Arellano, 2012, p. 48: «en el caso de Quevedo se acumulaban distintos enfoques y distintas corrientes, desde la sátira latina a los padres de la Iglesia, sin faltar la rica tradición misógina medieval, que por distintos motivos atacaban a la mujer».

29. A propósito de la caricatura de la vieja tan recurrente en la escritura quevedesca, Mas, 1957, p. 51, sintetiza: «Son image obsède Quevedo. En vain l’extériorise-t-il, en traits rageurs, de mille façons. Jusqu’à la fin de sa vie, vieux lui-meme et décrépit, il burine encore l’image hallucinante»; Hernández Vargas, 2015, p. 161, especifica: «Quevedo adjudica diversos males y defectos a las viejas relacionadas con la hechicería y el celestinaje; las representa grotescas, hiperbolizadas, caricaturizadas, animalizadas y, al mismo tiempo, como personificaciones del mal»; don Francisco, por supuesto, se inserta en una línea satírica muy desarrollada en el ambito de la agudeza española coetánea, que no deja indiferente ni siquiera a autores que, de buenas a primeras, no se asociarían con el gusto por la caricatura femenina; acerca de Lope de Vega ver Trambaioli, 2015. En cuanto a la dueña como personaje risible, ver el ya clásico trabajo de Arco, 1953.

30. Ver Arellano, 1984, p. 62: «El motivo de la dama desdeñosa se conserva, pero desplazado: el desdén se muestra ahora hacia el amante pobre o tacaño».

31. Destaquemos con Chevalier, 1992, pp. 64-72, que la caricatura a base de apodos, en la cual Quevedo es un auténtico maestro, es una de las principales técnicas del arte de motejar. 


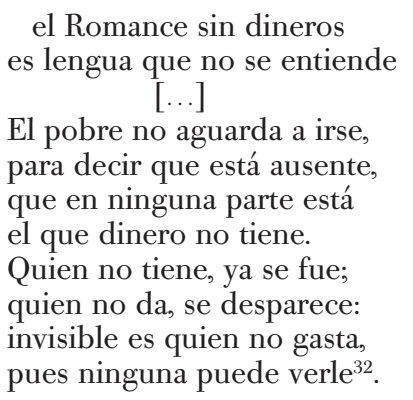

De acuerdo con el lema «Poderoso caballero es don Dinero» de la famosa letrilla del propio Quevedo ${ }^{33}$, la mujer, como todas sus congéneres, es pedigüeña, y el hombre adquiere un estatus social reconocido tan solo si tiene caudales que está dispuesto a dispensar con generosidad sin límites. Por su parte, el pobretón, "hambriento y desesperado», paga a la Dueña con la misma moneda, dirigiéndole una nueva sarta de grotescos apodos («Descomulgado avechucho», “Caín de tantos Abeles», “Mula de alquiler con manto», "Chisme revestido en sierpe»34), y al final evoca un exorcismo como si ella fuera un ser infernal, sintetizando así todas las tópicas caracterizaciones negativas de la mujer, es decir, la fealdad corporal, la codicia y la naturaleza diabólica heredada de la Eva bíblica ${ }^{35}$.

Otra mujer que no quiere saber nada de pretendientes pobres es doña Justa en la Segunda Parte del entremés de Diego Moreno. Habiéndose quedado viuda, es requerida por Diego Verdugo, del cual estaba ya prendada antes de la muerte del esposo. Aun fingiendo prostración por la pérdida del marido, se consuela muy pronto, al saber que un hombre rico, galán y liberal -tal se lo pintan Gutiérrez y doña Paula- la pretende. Y a doña Paula que le pregunta: «Pues, ¿no decía que ya se habían acabado los hombres para vuesa merced?», contesta: «Entiéndese los pobres y feos, que ricos y galanes son rico bocado y más con la salsa de ser liberales» ${ }^{36}$. Sin embargo, por la ley del contrapunto, a doña Justa le espera la amarga sorpresa de que Verdugo es un auténtico tirano.

32. Quevedo, “Advertencia de una Dueña a un Galán pobre», en Poesía varia, pp. 420422 , respectivamente vv. 1, 2-3, 23-24, y 45-52.

33. Sabido es que, en todo caso, la letrilla quevedesca se inserta en toda una tradición; ver al respecto Traver Vera, 1999.

34. Quevedo, “Advertencia de una Dueña a un Galán pobre», en Poesía varia, p. 424, vv. $89-92$

35. Arellano, 2012, p. 59, sintetiza así las peculiaridades de la figura de la mujer en la literatura satírica: «Todas las mujeres de este sector son enemigas del hombre, venales y adúlteras, infieles y pedigüeñas».

36. Quevedo, Segunda parte del entremés de Diego Moreno, en Teatro completo, p. 347. 
El que acabamos de apuntar es, con evidencia, un leitmotiv del teatro breve quevedesco ${ }^{37}$. En el Entremés de los enfadosos, que termina con un baile, el coro (TODos) asume el punto de vista de doña Luisa y doña Lorenza, que es el mismo de todas las mujeres pedigüeñas y codiciosas de la escritura de don Francisco: «Jesús, ¿qué tengo? / Asco de los pobres / en solo verlos». Según destaca con malicia el alguacil, la primera “Antes de conocer pide a la gente / y es una pedidora supitaña) ${ }^{38}$. En el baile «Las valentonas, y Destreza», Maripizca, mujer apicarada y ladrona, se niega de forma contundente al que no tenga recursos económicos, vinculando jocosamente su presunto honor al trueque monetario con un ingenioso juego de palabras que remite, a la vez, a su destreza con la espada:

Para el que me embiste

pobre y en cueros,

siempre es mi postura

puerta de hierro ${ }^{39}$.

En el capítulo v del Libro in del Buscón, Pablo se prenda de la moza de una posada y para conquistarla simula en balde ser rico, asumiendo la identidad de un hombre de negocios; pero cuando envía a un amigo a preguntar por el señor don Ramiro de Guzmán, las huéspedas contestan que allí vive «un don Ramiro de Guzmán, más roto que rico, pequeño de cuerpo, feo de cara y pobre s ${ }^{40}$. De acuerdo con la ideología aristocrática inherente a la pluma quevediana, el pícaro protagonista, con su aspecto destartalado, no consigue ocultar sus bajos orígenes que le impiden conseguir los favores de la mujer ${ }^{41}$. Por cierto, un fragmento de la Premática destos reinos parece dedicado a todos los Pablos que pretenden ser con el engaño lo que no son: «sabiendo las varias disimulaciones de los hombres vagamundos y pobres, mandamos que ninguno de aquí adelante llame picado a lo que verdaderamente es roto» ${ }^{42}$. Según vamos viendo, este último adjetivo, que remite al vestido andrajoso, resulta ser, de hecho, un sinónimo de 'pobre?.

37. Apunta a este respecto Alonso Veloso, 2007, p. 226: «El tema de la avaricia femenina, origen de numerosos tropos en las letrillas y predominante en los bailes quevedianos, se encuentra ya en las primeras manifestaciones de este subgénero teatral, por ejemplo en el que Cotarelo supone el más antiguo conservado, el "Baile del pastoral"». 399.

38. Quevedo, Entremés de los enfadosos, en Teatro completo, respectivamente pp. 402 y

39. Quevedo, «Las valentonas, y Destreza», en Poesía varia, p. 335, vv. 53-56.

40. Quevedo, El Buscón, pp. 250-251.

41. Subrayemos con Ynduráin, en El Buscón, p. 48, que «Pablos jamás usurpa nada, lo intenta, y fracasa sistemáticamente. Estos intentos de alcanzar el rango de caballero, unidos a la imposibilidad de lograrlo, sirven para prestigiar la condición noble como clase o grupo».

42. Quevedo, Pregmática de aranceles generales, en Prosa festiva, p. 161. 
Con una paradoja que el ingenioso juego de palabras pone de relieve en las Cartas del Caballero de la Tenaza, la falta de dinero del hombre puede hacer que las mujeres se conviertan festivamente en arrepentidas:

Bellaconas, ¿qué ha sido esto? Yo echo de ver que para convertiros no hay otra cosa como sacaros un gastado. Todas os habéis vuelto a Dios en viéndome sin blanca. Cosa devotísima debe ser un pobre, y vuestra calavera es bolsa vacía ${ }^{43}$.

Consideremos que en el lenguaje aurisecular el mayordomo de lo gastado es cel criado a quien no le subministran los medios correspondientes para el gasto» (Aut), siendo, así, una de las muchas figurillas de la pobreza que enriquecen la galería de tipos sociales y el campo semántico correspondiente en la escritura de Quevedo.

En la Premática del Tiempo se alude nuevamente al menosprecio con que las damas tratan a los pretendientes que no se muestran generosos recurriendo a una determinada figura de la mendicidad:

Sabiendo lo que estima un galán que se le caiga a su dama un guante, para levantarle y tenerle por prenda, declaramos que no se le deja ella caer por hacerle favor, sino para que le compre otros mejores, o para tratarle, si no se los compra, como a pobre vergonzante y darle un guante para que como $[\ldots]$ tal pida limosna ${ }^{44}$.

Explica Autoridades que el pobre vergonzante es cel que tiene vergüenza o lo que la ocasiona. Aplícase regularmente al pobre de obligaciones, que pide secretamente, y con recatom. Una variante maliciosa de la figura del vergonzante se incrusta en las ya mencionadas Cartas del Caballero de la Tenaza, resultando evidente que la caridad que el hombre pretende corresponde a unos favores sexuales. El yo paramimético, dirigiéndose a una mujer, escribe:

Es tanto lo que dicen de su caridad y virtud de vuesas mercedes que me ha dado atrevimiento a pedirles algo de limosna. Yo soy un amante mendigo envergonzante, que ni me está bien andar de casa en casa, ni puedo, porque en todas piden a cuatro cuartos; esme fuerza valerme de las buenas. Suplico a vuesa merced se duela de mi necesidad y trabajo. Y si me hubiere de hacer caridad, sea a escuras y de noche ${ }^{45}$.

Con matices diferentes, también en la poesía amorosa, más concretamente en un soneto del canzoniere a Lisi, halla cabida la equivalencia entre amante y hombre necesitado ${ }^{46}$, recurriendo a la idea neoplatóni-

43. Quevedo, Cartas del Caballero de la Tenaza, en Prosa festiva, p. 288.

44. Quevedo, Premática del Tiempo, en Prosa festiva, p. 223.

45. Quevedo, Cartas del Caballero de la Tenaza, en Prosa festiva, p. 278.

46. Alonso, 1966, p. 538, nos recuerda que «el poeta burlesco, el satírico, el filosófico y el erótico no están, por los temas, netamente diferenciados, pues cada uno de estos 
ca del enamorado como un ser enajenado que aquí por metonimia se reduce a su corazón que nada $-\mathrm{y}$ ahoga- en los procelosos piélagos dorados de la cabellera de la amada: «Avaro y rico, y pobre, en el tesoro / el castigo y la hambre imita a Midas, / Tántalo en fugitiva fuente de oro» ${ }^{47}$. La carencia, padecida como una punición infernal que asimila al hombre a trilladas figuras míticas negativas, se vincula a la mujer, identificada, mediante el color del pelo, con el rubio metal. De esta manera, e incluso en unos versos líricos, la dama no deja de ser connotada en términos negativos, resultando huidiza y $\mathrm{cruel}^{48}$, además de relacionarse metafóricamente con ese mismo oro que en la poesía satírica es la conditio sine qua non para que la mujer no tenga ningún reparo en entregarse sin más.

Por otra parte, también la figura femenina puede ser descrita o representada por su pobreza; tal es el caso de Bárbara, personaje tracista que, tras engañar a todo el mundo en la Primera Parte del Entremés que lleva su nombre, en la Segunda, al parecer, ha quedado viuda y arruinada, porque el marido se había embarcado con todas sus joyas y se había anegado a vista de la Florida, “dejando a la triste en notable pobreza» ${ }^{49}$. Pese a sus embustes, sigue teniendo a dos pretendientes: Artacho, un bellacón, y el napolitano Ascanio, que se revelará un violento mandón. Bárbara opta por volver a casarse con el italiano, aun habiendo aceptado por codicia una cadena de Artacho. Con todo, al final vuelve a aparecer su marido, quien no había perecido en el naufragio, y ella consigue burlar a los dos rivales, quedándose con la cadena. En este mismo sentido, el entremés es el triunfo del tipo de la mujer pedigüeña y engañosa, y el motivo de la pobreza sirve para evidenciar las trazas femeninas que tienen como objetivo el de cazar a un marido capaz de garantizarle una vida acomodada.

En la Pregmática que han de guardar las hermanas comunes se ponen en solfa ciertas mujeres sevillanas que ejercen de prostitutas disimulando su pobreza mediante la técnica caricaturesca de la animalización y su asimilación a la figura del pordiosero:

nos plu[go] ordenar por [las] exorbitantes arrogancias de las cotorreras que bajan de Sevilla en cueros que no digan siempre, por disculpar su pobreza, que aguardan trece cofres de ropa blanca que dejaron en tal parte

campos tiene una zona de secancia con los otros».

47. Quevedo, “En crespa tempestad del oro undoso», en Poesía varia, p. 243, vv. 12-14.

48. Ver al respecto Profeti, 1984, p. 97, quien, en las huellas del análisis de Molho, asienta: "Quevedo insomma non potrà mai "appropriarsi" dello [ sic] chioma della dama, che diventa anzi tranello mortale, mare incendiato, vita (alimentazione) negata; e questa capigliatura è metonimia di un corpo inattingibile, anzi, pericoloso, fonte solo di timore e di orrore».

49. Quevedo, Segunda parte del entremés de Bárbara, en Teatro completo, p. 302. 
con una mulata y dos criados enfermos, sino que confiesen que vienen como nacieron, y se vendan por mendigas y invergonzantes ${ }^{50}$.

De hecho, la mujer, por sí sola, ofrece un sin fin de pretextos para elaborar el tema de la pobreza, aunque sea de forma figurada. Para brindar un ejemplo significativo, en el romance satírico-burlesco «Cura una moza en Antón Martín la tela que mantuvo», el cuerpo deformado de Marica, enferma de sífilis por ser, entre líneas, una prostituta, se describe con toda clase de detalles grotescos que remiten a sus mermas físicas. Destaquemos el siguiente:

Por la garganta y el pecho se ve, cuando quiere hablar, muchos siglos de capacha en pocos años de edad ${ }^{51}$.

Crosby anota que la capacha funciona aquí como «metáfora de la mendicidad (la capacha era la esportilla de palma en la que los religiosos de la Orden de san Juan de Dios solían recoger la limosna que pedían para los pobres » ${ }^{52}$, pero el término alude asimismo a la antigua profesión de la mujer que de joven ejercía de prostituta. Con respecto a la técnica de la caricatura femenina, en que don Francisco es un auténtico maestro, una parte del cuerpo de Marica resulta así burlescamente cosificado mediante uno de los múltiples ejemplos del uso de la sinécdoque en el ornato burlesco autorial. En concreto la capacha es el contenedor en que deberían caber las monedas hurtadas al galán por la grotesca mujer ${ }^{53}$.

50. Quevedo, Pregmática que han de guardar las hermanas comunes, en Prosa festiva, p. 335; por lo que se refiere al término escogido por la pluma quevediana para deformar burlescamente la figura de dichas mujeres, ver Aut: «La hembra del papagayo, pájaro bien conocido, del tamaño de una paloma, de hermosos y varios colores, el pico corvo, y que con facilidad aprende y dice las palabras que se le enseñan, y por semejanza se llaman así las mujeres habladoras [...] ¿Qué diremos de tantos papagayos? ¿Y qué de tantas cotorreras, que ni entienden lo que piden a Dios, ni saben lo que ruegan?».

51. Quevedo, “Cura una moza en Antón Martín la tela que mantuvo», en Poesía varia, p. 397, vv. 25-28; según Mas, 1957, p. 190, el tratamiento médico de la sífilis que Marica recibe en el hospital tanto en dicho romance como en otra composición sobre el mismo tema, se relaciona implícitamente con la redención de la pecadora: “Lidée de la sueur expiatrice et rédemptrice doit retentir dans la conscience chrétienne de Quevedo», si bien la sátira quevedesca parece fijarse más bien en las lamentables condiciones físicas de la enferma con toda clase de detalles repugnantes.

52. Quevedo, “Cura una Moza en Antón Martín la tela que mantuvo», en Poesía varia, p. 397 , nota al v. 27 .

53. Alonso Veloso, 2007, p. 58, observa a dicho propósito: «Otra esfera de aplicación del recurso retórico de la sinécdoque muy común en estas composiciones tiene un matiz casi moral y se refiere de forma obsesiva al dinero, a su creciente importancia en la sociedad de la época y, en definitiva, al defecto de la avaricia. Se trata en realidad de un topos habitual en el género satírico, que Quevedo representa también por metonimia con términos como bolsa y sus sinónimos». 
Sabido es que en el número de las profesiones, blanco privilegiado de la zahiriente pluma satírica de don Francisco, los pasteleros siempre son acusados de meter los ingredientes más repugnantes en sus pasteles, incluyendo insectos y carne humana ${ }^{54}$. A esto mismo se refiere en clave conceptista la sarcástica voz poética de la letrilla «Deseado he desde niño», cuando prevé el destino de un hombre necesitado en clave macabro-grotesca:

\author{
El pobretón más cruel \\ que sin dineros se viere, \\ tendrá mosca, si se hiciere \\ en el verano pastel ${ }^{55}$.
}

Sobre la harapienta figura del mendigo, Quevedo elabora fragmentos memorables de su escritura. En el capítulo vi de El Buscón, Pablo, perseguido por unos vecinos y el confitero a quien había robado un cofín de pasas, a la vuelta de una esquina se envuelve en su capa y finge ser un pobre mendigo pisoteado por el ladrón, logrando engañar a todo el mundo. No por nada el episodio se inserta en un capítulo en cuyo subtítulo resaltan las «travesuras» del pícaro ${ }^{56}$.

En Vida de la corte y Capitulaciones matrimoniales los mendigos y pordioseros coinciden con los que, al tener defectos corporales, se aprovechan de ellos para robar. Con tintes pre-goyescos, escribe don Francisco: «Tienen mucho de flor, pues con la licencia de pobres suelen, en las iglesias, limpiar el lienzo o la caja al que con más diversión oye la misa; y entrándose en las casas, también acostumbran, a falta de gente, desaparecer lo que hallan más a mano ${ }^{57}$.

En la dimensión carnavalesca del teatro breve, Quevedo nos depara una jocosa exaltación del mundo miserable de los mendigos, echando mano de la tradición romanceril de las bodas rústicas ${ }^{58}$. En la Boda de pordioseros, que corresponde al octavo baile del corpus conservado, celebrada entre Merlo y Marica la Pindonga, participan «cuantos pobres y pobras / a la Fuente del Piojo / en sus zahúrdas moran »59. La ocasión festiva le permite al escritor pintar poéticamente un fresco apicarado y juguetón, con toda clase de detalles grotescos y de creaciones lingüísticas tan típicas de su estilo conceptista. A este último respecto apuntemos

54. Ver al respecto, Chevalier, 1992, pp. 119-120: «Huelga decir que Francisco de Quevedo igualmente admite en sus prosas y versos unas chanzas tradicionales que, si bien nos pueden sorprender, no chocaban a ningún lector del Siglo de Oro. Tal es el caso de los pasteles supuestamente rellenos de carne humana. La afirmación no pasa de ser una broma venerable que circuló por mucho tiempo a través de Europa».

55. Quevedo, «Deseado he desde niño», en Poesía varia, p. 286, vv. 64-67.

56. Quevedo, El Buscón, p. 149: «De las crueldades de la ama, y travesuras que yo hice».

57. Quevedo, Vida de la corte y Capitulaciones matrimoniales, en Prosa festiva, p. 232. 2013.

58. Acerca del género y de su elaboración por parte de Lope de Vega, ver Trambaioli,

59. Quevedo, Boda de pordioseros, en Teatro completo, p. 637. 
el uso de «clamistas» ${ }^{60} \mathrm{y}$ «zampalimosnas» como sinónimos de mendigos y pordioseros. Tratándose de un matrimonio entre pobres, el dote solo puede ser «de palabra», y la ceremonia acontece en la calle con una ingeniosa asimilación de los esposos a unos forzados en una galera:

Sentáronse en un banco

cual si fuera de popa,

que el matrimonio en pobres

es remo con que bogan ${ }^{61}$.

Al fin y al cabo, en la literatura festiva en lengua castellana ya la bisemia de la palabra esposas juega con la análoga identificación entre el matrimonio y el encarcelamiento. También, la condición apicarada de los cónyuges y de sus invitados remite al mundo del hampa y a la cárcel donde todos ellos deberían terminar. En efecto, estos últimos, aun en el cortejo nupcial, siguen pidiendo limosna y, de paso, roban con sus consolidadas y maliciosas técnicas; recortemos el siguiente fragmento:

Con niños alquilados

que de contino lloran

a poder de pellizcos

por lastimar las bolsas,

la taimada Gallega,

más bellaca que tonta,

entró de casa en casa

bribando la gallofa ${ }^{62}$.

En el remate de los versos, toma la palabra, cantando, Perico de la Gallofa, «carretero cosario / de la limosna», el cual no pierde la ocasión para subrayar la equivalencia entre pordioseros y mujeres pedigüeñas:

Hay lisiados que piden

a cuantos quieren

y muchachas lisiadas

por pedir siempre ${ }^{63}$.

60. Autoridades cita precisamente un pasaje quevedesco a propósito de este término: “Quev. Fort. Llevábalos un compañero panza al trote, insigne clamista».

61. Quevedo, Boda de pordioseros. Baile vIII, en Teatro completo, p. 638, v. 17, y p. 639, vv. $29-32$.

62. Quevedo, Boda de pordioseros. Baile viII, en Teatro completo, p. 641, acerca de la sátira de las gallegas, anota Mas, 1957, p. 17: «La gallega (la galicienne) occupe une place de choix dans cette triste galerie. Invariablement elle est privée d'occiput, plate de chignon, C'est là un des clichés les plus tyranniques de la littérature de l'époque».

63. Quevedo, Boda de pordioseros. Baile viII, en Teatro completo, p. 644, respectivamente vv. 133-134, y 135-138. 
Lo mismo ocurre en un fragmento de las Cartas del Caballero de la Tenaza, donde el yo paramimético, teniendo que escribir a su dama, elucubra lo siguiente:

Estando pensando qué respondería a las cosas que vuesa merced me pide, se me vinieron a la memoria aquellas inefables palabras que a los pobres se dicen con lástima y a las mujeres con razón: «No hay que dar». Señora mía, yo bien entendí que había órdenes mendicantes, pero no niñas mendicantes sin orden ${ }^{64}$.

Notemos que uno de los raros fragmentos en que el motivo de la pobreza se asocia a la figura femenina en términos serios se halla en la Carta de las calidades de un casamiento. El hecho de que esta prosa sea dedicada a doña Inés de Zúñiga y Fonseca, condesa de Olivares, explica el tono contenido de la voz que enuncia. Pasando revista a las cualidades de la esposa ideal, defiende el principio del justo medio de lo que un hombre puede moralmente ambicionar:

No la quiero rica, ni pobre, sino con hacienda; que ni ella me compre a mí ni yo a ella. La hacienda, donde hubiere nobleza y virtud, no se ha de echar menos; pues, tiniéndolas, quien la deja por pobre es vilmente rico; y no las tiniendo, quien la cudicia por rica es civilmente pobre ${ }^{65}$.

Así y todo el hombre necesitado no es necesariamente un miserable sin ton ni son, sino que puede coincidir hasta con un hidalgo ${ }^{66}$. Aún en El Buscón, Pablo topa con un licenciado pobre en el capítulo v del libro II, tras huir de Segovia y del tío verdugo. Dicho personaje no solo no tiene nada que envidiar al arquetipo del Lazarillo ${ }^{67}-\mathrm{el}$ cual, en todo caso, se conforma a partir de un planteamiento ideológico opuesto- sino que lo supera con creces en tanto que figurilla risible muy presente en la corte:

Veme aquí v.M. un hidalgo hecho y derecho, de casa de solar montañés, que, si como sustento la nobleza, me sustentara, no hubiera más que pedir.

64. Quevedo, Cartas del Caballero de la Tenaza, en Prosa festiva, p. 289.

65. Quevedo, en Carta de las calidades de un casamiento, en Prosa festiva, p. 463.

66. Destaquemos con Rodríguez, 1994, p. 152, que en un plano socio-antropológico a este "se le ve como un marginado "anacrónico" mientras que el pícaro es perfectamente contemporáneo a la "crisis"»; p. 155: “el relato se configura a partir de lo privado precisamente para ponerlo en contraste con la esfera de lo público que es a la que el escudero se aferra con desesperación»; p. 157: «un hidalgo, para ser reconocido como tal, no sólo no puede mendigar sino que tampoco puede incorporarse a las nuevas relaciones de trabajo».

67. Ver Arellano, 1984, p. 92: «La falsa nobleza inspira a Quevedo dos caricaturas principales: la del hidalgo raído y parásito (cuyos arquetipos magistrales son don Toribio en el Buscón y don Diego de Noche en el Sueño de la Muerte), y el caballero chanflón del soneto 613, más disimulado en su apariencia exterior y usurpador del discurso y formas de conducta del verdadero noble. El primer tipo incorpora generalmente el motivo de la dificultad de conservar las apariencias, y puede remontarse al escudero del Lazarillo. En Quevedo se acentúa su linaje plebeyo o infecto: no se trata de hidalgos arruinados, sino de falsos hidalgos parásitos». 
Pero ya, señor licenciado, sin pan ni carne, no se sustenta buena sangre, y por la misericordia de Dios, todos la tienen colorada, y no puede ser hijo de algo el que no tiene nada. [...] He vendido hasta mi sepultura, por no tener sobre qué caer muerto, que la hacienda de mi padre Toribio Rodríguez Vallejo Gómez de Ampuero - que todos estos nombres tenía-, se perdió en una fianza. Sólo el don me ha quedado por vender, y soy tan desgraciado que no hallo nadie con necesidad dél, pues quien no le tiene por ante, le tiene por postre, como el remedón, azadón, pendón, blandón, bordón y otros asín ${ }^{68}$.

Tanto es así que en el capítulo siguiente don Francisco dota al miserable hidalgo de una digna compañía de cofrades: «Entre nosotros nos diferenciamos con diferentes nombres; unos nos llamamos caballeros hebenes; otros, güeros, chanflones, chirles, traspillados y caninos» ${ }^{69}$, agotando la posibilidad de superar el ejemplo de su hiperbólico desfile barroco de figurillas de la pobreza, disfrazadas de hidalguía postiza.

En las múltiples e intrigantes posibilidades que la pluma satíricoburlesca le depara a Quevedo, cabe señalar algunos ejemplos alegóricos y / o metafóricos de la pobreza aplicada a elementos naturales o a entidades abstractas. En el romance «Descubre Manzanares secretos de los que en él se bañan», el río madrileño, notoriamente de poco caudal ${ }^{70}$, se describe como si de un mendigo se tratara: «Muy ético de corriente, / muy angosto y muy roído, / con dos charcos por muletas». Conforme a esta visión alegórica, hablando directamente, el río personificado confiesa que va limosneando en las arenas «andrajos de agua» ${ }^{71}$.

En varios fragmentos de sus obras se incrusta la idea de que la época contemporánea es miserable, pedigüeña y avara como las mujeres, de acuerdo con la actitud pesimista del escritor ${ }^{72}$. En el cierre del Entremés de la destreza los músicos cantan:

Tan, tan, tan, tan pobres los tiempos van que piden y no nos dan, dan, dan, dan ${ }^{73}$.

68. Quevedo, El Buscón, pp. 208-209.

69. Quevedo, El Buscón, p. 211.

70. Tal como destaca Arellano, 1984, p. 110, el Manzanares es uno de los lugares madrileños más reiterados en la poesía burlesca, junto con la Plaza Mayor, la Casa de Campo, el Retiro, la ermita del Ángel, la Puente Segoviana y el hospital de Antón Martín.

71. Quevedo, «Descubre Manzanares secretos de los que en él se bañan», en Poesía varia, p. 427, respectivamente vv. 17-19, y 29.

72. Subrayemos con Maravall, 1996, pp. 97-98: «se trata no de un pesimismo antropológico, sino social, que no promueve la crítica del hombre, al modo de Milton, salvo rara excepción de pasada o ya en alguna de las obras tardías de carácter religioso, sino una crítica de las profesiones. La inestabilidad de la sociedad revela que en ella hay una carga de injusticia, de desigualdad, de dolor, y ni se puede suprimir directamente el mal ni reformar la sociedad en busca de ese fin».

73. Quevedo, Entremés de la destreza, en Teatro completo, p. 434. 
Subrayemos que el mismo estribillo, aun con un par de variantes, remata el Baile $\mathrm{x}$, Las estafadoras ${ }^{74}$.

En el capítulo in del Libro in de El Buscón, Pablo lee a un sacristán su Premática del desengaño contra los poetas güeros, chirles y hebenes, categoría profesional contra la cual don Francisco vierte mucha tinta siguiendo una línea satírica muy en $\operatorname{boga}^{75}$, y en un punto determinado afirma:

Y por cuanto el siglo está pobre y necesitado, mandamos quemar las coplas de los poetas, como franjas viejas, para sacar el oro, plata y perlas, pues en los más versos hacen sus damas de todos metales, como estatuas de $\mathrm{Nabuco}^{76}$.

De esta manera el escritor consigue burlarse, entre otras cosas, de la parafernalia metafórica y de los convencionalismos de la hueca poesía de imitación petrarquista. De hecho, el sacristán, versificador de ínfima calidad, encarna la tópica y risible figura del poeta pobre: «traia él una sotana con canas, de puro vieja, y con tantas cazcarrias que, para enterrarle, no era menester más de entregársela encimas ${ }^{77}$.

Una imagen análoga, la de una prenda desgastada de un mendigo, le sirve a don Francisco en el Cuento de cuentos para construir una ingeniosa metáfora de reflexión filológica:

La habla que llamamos castellana y romance tiene por dueños a todas las naciones: los árabes, los hebreos, los griegos y los romanos naturalizaron con la vitoria tantas veces nuestro idioma, que la sucede lo que a la capa del pobre, que son tantos los remiendos, que su paño se equivoca con ellos ${ }^{78}$.

En un ámbito temático análogo, en el «Prólogo» de los Sueños y discursos, el yo autorial para referirse a la transmisión manuscrita de su obra, que amenaza con estragarla, recurre en clave metafórica al motivo de la miseria del soldado que vuelve de la guerra en condiciones miserables:

de cuantos han leído algo de estos Sueños y discursos, como de los han oído referir y celebrar algunas o alguna de las innumerables agudezas que contienen, lastimándose de verlos ir manuscritos, tan adulterados y falsos, y muchos a pedazos y hechos un disparate sin pies ni cabeza, y tan desfigurados como el soldado desdichado que habiendo salido de su tierra para la guerra con bizarría, tallazo, galas y plumas, vuelve a ella después de muchos años más desgarrado y rompido que soldado, con un ojo menos, hecho un

74. Quevedo, Las estafadoras. Baile x, en Teatro completo, p. 651, vv. 53-56.

75. Acerca de la sátira contra los poetas profesionales, ver por ejemplo Herrero, 1977, pp. 239 y ss.

76. Quevedo, El Buscón, p. 184; el mismo fragmento se incrusta en la Premática del Desengaño contra los poetas güeros, en Prosa festiva completa, pp. 186-187.

77. Quevedo, El Buscón, pp. 186-187.

78. Quevedo, Cuento de cuentos, en Prosa festiva, p. 389. 
monóculo, medio brazo, con una pierna de palo, y todo él hecho un milagro de cera, bueno para ofrecido, con el vestido, de la munición, sin color determinado, desconocido y roto, pidiendo limosna ${ }^{79}$.

Observemos que Quevedo, desde su atalaya aristocrática que, por lo general, lo lleva a mantener una postura de defensa de la milicia, en tanto que parte integrante del orden establecido ${ }^{80}$, no suele vincular la figura del soldado miserable a la lamentable condición de los militares de su propio país, si bien el motivo de la pobreza de los tercios españoles es, de hecho, un tópico coetáneo relacionado con el mal estado de las finanzas de la corona ${ }^{81}$.

Finalmente, la metáfora de la pobreza se declina en clave retórica para formular una excusatio propter infirmitatem en el incipit de la "Pobreza. Segunda Fantasma de la Vida», capítulo de Virtud militante contra las cuatro pestes del mundo: «El tratado de la Pobreza, y el caudal con que le escribo, es pobre, y mis estudios la pobreza misma» ${ }^{82}$.

A la luz de lo expuesto, me parece evidente que el tratamiento que Francisco de Quevedo reserva a las figuras y figurillas del tipo que ocupa el último eslabón de la escala social se inserta, como es de esperar, en un discurso ideológico bien determinado: el que se ciñe a su moralismo de corte estoico y que defiende el estatus quo. Y esto se echa de ver de manera especial en su aprovechamiento festivo. La galería de tipos y situaciones espigados en la prosa, en la poesía y en el teatro quevedescos muestran que el tema de la pobreza se revela uno de los más fértiles en relación con su capacidad creadora -ingeniosa y conceptista- de neologismos y caricaturas. Al mismo tiempo, depara múltiples aspectos que armonizan a la perfección con la misoginia cultural de la época y del propio autor.

79. Quevedo, «Prólogo», en Sueños y discursos, p. 69.

80. Ver Ynduráin, en Quevedo, Poesía varia, p. 57: «la defensa de la milicia es constante en Quevedo; recordemos su decidida defensa del patronazgo de Santiago; así, cuando en el Buscón aparece el soldado ridículo, lo es porque no es un soldado verdadero, de manera que se inserta con toda naturalidad en la serie burlesca donde aparece: falso ermitaño, falso poeta, falso esgrimidor, falso caballero y soldado falso»; por lo general, el soldado que es objeto de sátira en la escritura quevediana corresponde a la figura clásica del militar fanfarrón, moldeada sobre el miles gloriosus de Plauto; ver al respecto NoltingHauff, 1968, pp. 119-120.

81. Este motivo lo encontramos de paso, por ejemplo, en Pobreza no es vileza de Lope de Vega; ver Trambaioli, 2016, p. 115: «El galán y la hermana están obligados a ocultar su identidad, despachándose respectivamente por Mendoza y Laura. Al no poder ir a luchar junto con la mujer, don Juan decide dejarla en casa de Rosela, una dama flamenca que él había defendido de unos soldados españoles quienes, empujados por falta de pagas, pretendían robarle sus joyas. [...] el tema de la pobreza resulta central en la trama, dado que [...] el protagonista hasta el final vive como los demás soldados españoles, es decir, sin recursos económicos. Como es de esperar, sus virtudes, humanas y bélicas, compensan su miseria material». En cuanto a Quevedo, se trata de un tema bastante ignorado por la crítica y que haría falta revisar, tal como ha propuesto ya en su momento García Lorenzo, 1996, p. 352, fijándose específicamente en la figura del soldado pretendiente.

82. Quevedo, Virtud militante contra las cuatro pestes del mundo, p. 262 [he modernizado la grafía]. 
En efecto, según muchos de los ejemplos reseñados ponen de relieve, la figura del mendigo se puede jocosamente asimilar a la de la mujer pedigüeña, mientras que en la vertiente masculina el pordiosero ambiciona una caridad de naturaleza erótica. En ambos casos, la relación entre los dos sexos depara, pues, a la pluma satírica corrosiva de Quevedo la oportunidad de adaptar la figura del pobre a una visión carnavalizada, esto es: rebajada y materialista, del tema amoroso. Pero, incluso algunas reflexiones filológicas y morales del escritor dan pie a elaboraciones metafóricas inéditas de la figura o de algún accesorio del miserable. En definitiva, la pluma quevedesca nunca deja de asombrarnos por su habilidad de aprovecharse de un tipo humano -en el caso escudriñado en estas páginas el del pobre- para aludir con suma argucia y gusto barroco por la variatio a las realidades y situaciones más disparatadas.

\section{BibLiografía}

Alonso, Dámaso, «Quevedo: desgarrón afectivo», en Poesía española, Madrid, Gredos, 1966, pp. 497-580.

Alonso Veloso, María José, El ornato burlesco en Quevedo. El estilo agudo en la lírica jocosa, Sevilla, Universidad de Sevilla, Secretariado de Publicaciones, 2007.

Arco, Ricardo del, “La "dueña” en la literatura española», Revista de Literatura, 3, 1953, pp. 293-343.

Arellano, Ignacio, Poesía satírico burlesca de Quevedo, Pamplona, Eunsa, 1984.

Arellano, Ignacio, “Modelos femeninos en la poesía de Quevedo», La Perinola, 16, 2012, pp. 47-63.

Calderón de la Barca, Pedro, El gran teatro del mundo. El gran mercado del mundo, ed. Eugenio Frutos Cortés, Madrid, Cátedra, 1987.

Chevalier, Maxime, Quevedo y su tiempo: la agudeza verbal, Barcelona, Editorial Crítica, 1992.

Gactó Fernández, Enrique, «La administración de justicia en la obra satírica de Quevedom, en Homenaje a Quevedo. Actas de la II Academia Literaria Renacentista. Universidad de Salamanca, 10, 11 y 12 de diciembre, 1980, ed. Víctor García de la Concha, Salamanca, Universidad de Salamanca, 1996, pp. 133-162.

García Lorenzo, Luciano, «Quevedo y sus soldados pretendientes», en Homenaje a Quevedo. Actas de la II Academia Literaria Renacentista. Universidad de Salamanca, 10, 11 y 12 de diciembre, 1980, ed. Víctor García de la Concha, Salamanca, Universidad de Salamanca, 1996, pp. 347-354.

Geisler, Eberhard, El dinero en la obra de Quevedo. La crisis de identidad en la sociedad feudal española a principios del siglo XVII, Kassel, Reichenberger, 2013.

Hernández Vargas, Jaime, «Dos viejas celestinas y hechiceras en la lírica quevediana: fisonomía y retratos sociales como instrumentos punitivos», $L a$ Perinola, 19, 2015, pp. 161-180.

Herrero, Miguel, Oficios populares en la sociedad de Lope de Vega, Madrid, Castalia, 1977.

Iffland, James, Quevedo and the grotesque, London, Tamesis Books, 1978, 2 vols. 
Maravall, José Antonio, «Sobre el pensamiento social y político de Quevedo (Una revisión)», en Homenaje a Quevedo. Actas de la II Academia Literaria Renacentista. Universidad de Salamanca, 10, 11 y 12 de diciembre, 1980, ed. Víctor García de la Concha, Salamanca, Universidad de Salamanca, 1996, pp. 69-131.

Mas, Amédée, La caricature de la femme, du mariage et de l'amour dans l'oeuvre de Quevedo, Paris, Ediciones Hispano-Americanas, 1957.

Nider, Valentina, «El Job de Quevedo y la indignación», en Serenísima palabra. Actas del x Congreso de la Asociación Internacional Siglo de Oro (Venecia, 14-18 de julio de 2014), ed. Anna Bognolo, Florencio del Barrio de la Rosa, María del Valle Ojeda Calvo, Donatella Pini y Andrea Zinato, Venecia, Edizioni Ca' Foscari, 2017, pp. 125-145.

Nolting-Hauff, Ilse, Visión, sátira y agudeza en los «Sueños» de Quevedo, Madrid, Editorial Gredos, 1968.

Peraita, Carmen, «El contrato de caridad y los cambios de la gloria: concepciones quevedianas de la pobreza», en Quevedo en Manhattan, ed. Ignacio Arellano y Victoriano Roncero, Madrid, Visor, 2004, pp. 203-216.

Prieto, Antonio, «De un símbolo, un signo y un síntoma», Prohemio, 1, 1970, pp. 357-395.

Profeti, Maria Grazia, Quevedo: la scrittura e il corpo, Roma, Bulzoni Editore, 1984.

Quevedo, Francisco de, El Buscón, ed. Domingo Ynduráin, Madrid, Cátedra, 1991.

Quevedo, Francisco de, Poesía original completa, ed. José Manuel Blecua, Barcelona, Planeta, 1999.

Quevedo, Francisco de, Poesía varia, ed. James O. Crosby, Madrid, Cátedra, 1988.

Quevedo, Francisco de, Prosa festiva completa, ed. Celsa Carmen García Valdés, Madrid, Cátedra, 1993.

Quevedo, Francisco de, Sueños y discursos, ed. Felipe C. R. Maldonado, Madrid, Clásicos Castalia, 1984.

Quevedo, Francisco de, Teatro completo, ed. Ignacio Arellano y Celsa Carmen García Valdés, Madrid, Cátedra, 2011.

Quevedo, Francisco de, Virtud militante contra las cuatro pestes del mundo, en Obras de Francisco de Quevedo Villegas.... divididas en tres tomos, Amberes, por Henrico y Cornelio Verdussen 1699, vol. 2, pp. 193-304, consultado por Biblioteca Virtual Miguel de Cervantes.

Rodríguez, Juan Carlos, La literatura del pobre, Granada, Editorial Comares, 1994.

Roncero, Victoriano, «El humor y la risa en las preceptivas de los Siglos de Oro», en Demócrito áureo. Los códigos de la risa en el Siglo de Oro, Sevilla, Renacimiento, 2006, pp. 287-328.

Schwartz Lerner, Lía, «Sátira y filosofía moral. El texto de Quevedo», en Actas del ${ }_{I X}$ Congreso de la Asociación Internacional de Hispanistas: 18-23 agosto 1986 Berlín, ed. Sebastian Neumeister, Frankfurt am Main, Vervuert Verlag, 1989, pp. 619-627.

Trambaioli, Marcella, «Romance a las venturosas bodas que se celebraron en la insigne ciudad de Valencia, de Lope de Vega: entre tradición popular y parateatralidad cortesana", en Teatro español de los Siglos de Oro. Dramaturgos, textos, escenarios, fiestas, dir. José M. ${ }^{\mathrm{a}}$ Díez Borque, ed. M. ${ }^{a}$ Soledad Arredondo 
Sirodey, Ana Martínez Pereira y Gerardo Fernández San Emeterio, Madrid, Visor, 2013, pp. 243-265.

Trambaioli, Marcella, “Quevedo, Lope y la mujer fea», La Perinola, 19, 2015, pp. 271-305.

Trambaioli, Marcella, «El galán pobre en el teatro de Lope de Vega: entre autobiografía y ficción», en Estrategias picarescas en tiempos de crisis, ed. Amaranta Saguar García y Hannah Schlimpen, dir. Folke Gernert y Miguel GarcíaBermejo Giner, Hispanistik Trier, FB-II Romanistik, 2016, en-línea, pp. 109129.

Traver Vera, Ángel Jacinto, “El motivo del “dinero todopoderoso” en Quevedo: precedentes clásicos de la expresión "poderoso caballero es Don Dinero"», Exemplaria, 3, 1999, pp. 37-50.

Vilanova, Antonio, «Fuentes clásicas y erasmianas del episodio del Dómine Cabra», en Homenaje a Quevedo. Actas de la II Academia Literaria Renacentista. Universidad de Salamanca, 10, 11 y 12 de diciembre, 1980, ed. Víctor García de la Concha, Salamanca, Universidad de Salamanca, 1996, pp. 355-388. 
